\title{
Water Footprint Analysis in Dairy Industry in India
}

\author{
Zareena B. Irfan and Mohana Mondal
}

\begin{abstract}
Water footprint is a multidimensional indicator, showing water consumption volumes by source and by type of pollution; all components of a total water footprint are specified geographically and temporally. The issue of water scarcity in India is getting serious day-by-day. Water scarcity is fast becoming urban India's number one woe, with government's own data revealing that residents in 22 out of 32 major cities have to deal with daily shortages. In this paper the authors calculate the water footprint in Indian dairy industry to assess its water intensity.
\end{abstract}

Index Terms - Water scarcity, water footprint, dairy industry, India.

\section{INTRODUCTION}

Humanity relies on ecosystem products and services .These products and services include resources, waste absorptive capacity, and space to host urban infrastructure. Human demand has well exceeded the levels of regenerative and absorptive capacity of the biosphere which is evident from the present scenario of environmental degradations like deforestation, collapsing fisheries, accumulation of carbon dioxide in the environment in excess amount leading to global warming. Careful management of human interaction with the biosphere is essential to ensure future prosperity and sustainable development. Regenerative capacity and waste absorbing capacity of the environment has to be taken into account in order to pave way for progress in a sustainable manner. The National Footprint Accounts includes the supply and demand sides of the ecology along with prevailing historical trends and aim to provide ways that may be applied across countries over time. The National Footprint Account provides us with the ability to monitor the anthropogenic pressures on the environment. The effects of these pressures are severe and include climate change, fisheries collapse, land degradation, land use change, food consumption, etc.

"Water footprint" means the amount of water used by a household or a country, or the amount used for a given task or for the production of a given quantity of some product or crop. The term "water footprint" is often used to refer to the amount of water used by an individual, community, business, or nation. The water footprint of a product is the volume of freshwater used to produce the product, measured over the full supply chain. Water footprint is the amount of water used in and around our home, school or office throughout the day. It includes the water used directly (e.g., from a tap) and also indirectly. It also includes the water it took to produce the food we eat, the products we buy, the energy we consume and

Manuscript received July 23, 2015; revised September 18, 2015.

The authors are with Madras School of Economics, Gandhi Mandapam Road, Chennai -600025, India (e-mail: zareena@mse.ac.in). even the water we save when we recycle. We may not drink, feel or see this virtual water, but it makes up the majority of our water footprint. The concept of "virtual water" deserves special mention in this regard. Virtual water trade refers to the hidden flow of water if food or other commodities are traded from one place to another. The concept of virtual water enables us to realize how much water is needed to produce different goods and services. In semi-arid and arid areas, idea about the virtual water value of a good or service can be useful towards determining how best to use the scarce water available. The concept of virtual water content of a commodity is defined as the volume of water that is actually used to produce the commodity, measured at the place where the commodity is actually produced. The inverse of the virtual water content is known as the water productivity of a crop.

Water footprint is a multidimensional indicator, showing water consumption volumes by source and by type of pollution; all components of a total water footprint are specified geographically and temporally. The water footprint can be divided into an internal and an external water footprint. The internal component covers the use of domestic water resources and the external component covers the use of water resources elsewhere. The agricultural component corresponds with the water used in the agricultural sector (i.e. in the form of crop evapotranspiration or water pollution), the industrial component corresponds with the water use in the industrial sector and the domestic component with the water use in the domestic sector. Again, there are three types of water footprint namely- a) blue water footprint b) green water footprint and c) grey water footprint. The gray component has been introduced by Chapagain et al. (2006). The blue component covers the use of groundwater and surface water during the production of a commodity. The blue water footprint refers to consumption of blue water resources (surface and groundwater) along the supply chain of a product. 'Consumption' refers to loss of water from the available ground-surface water body in a catchment area. Losses occur when water evaporates, returns to another catchment area or the sea or is incorporated into a product. The green water footprint refers to consumption of green water resources (rainwater insofar as it does not become run-off). It covers the use of rain water for crop growth. The grey water footprint refers to pollution and is defined as the volume of freshwater that is required to assimilate the load of pollutants given natural background concentrations and existing ambient water quality standards. It covers the water required to dilute the water that is polluted during the production of the commodity.

With over one billion people, India currently has the world's second largest population. The estimate of the amount of people living in India in the year 2050 is 1.6 billion (United Nations, 2004). This is an increase in population of 
approximately $50 \%$ in the next fifty years. Next to this population growth the total Gross Domestic Product (GDP) growth in India is around 4.7\% (in 2012 (World Bank)). Furthermore, there currently is a net export of agricultural products from India, which has shown an increase in the past decade, which is likely to persist. These developments will lead to a large growth in the total food demand in India in the near future leading to an increase in agricultural activities. Most of the utilizable water supply in India is used for crop production [1], and thus an important criterion for the evaluation of a possible food supply strategy is the pressure on renewable water resources

The issue of water scarcity in India is getting serious day-by-day. Water scarcity is fast becoming urban India's number one woe, with government's own data revealing that residents in 22 out of 32 major cities have to deal with daily shortages. The worst-hit city is Jamshedpur, where the gap between demand and supply is a yawning 70\%. The crisis is acute in Kanpur, Asansol, Dhanbad, Meerut, Faridabad, Visakhapatnam, Madurai and Hyderabad — where supply fails to meet almost $30 \%$ of the demand - according to data provided by states which was placed in the LokSabha during the recently-concluded Parliament session by the urban development ministry. The figures reveal that in Greater Mumbai and Delhi - which have the highest water demand among all cities - the gap between demand and supply is comparatively less. The shortfall is $24 \%$ for Delhi and $17 \%$ for Mumbai. However, the situation is worse than that. For example, in Delhi, 3,156 million litres of water (MLD) is supplied against the requirement of 4,158 . But around $40 \%$ of the supply is lost in distribution resulting in a much wider gap between demand and supply than what's recorded.

\section{OBJECTIVE}

Previously no work has been done to analyse the water footprint in Indian industries though the same has been extensively done for Indian agricultural sector. In this paper the authors wish to capture the present day scenario of water footprint in India in Dairy Industry. Water footprint is calculated and at the end water footprint sustainability assessment has also been done. The target is to assess the water footprints related to the consumption of agricultural and industrial commodities in India and to assess the water scarcity in India.

\section{LITERATURE SURVEY}

The potential benefits of a more sustainable dairy industry are substantial and far-reaching. The industry is a large economic driver globally, which represents approximately $\$ 330$ billion annually and is expected to grow to nearly $\$ 400$ billion by 2015. With over 9 million dairy cows and approximately 89 billion $\mathrm{kg}$ of milk produced in 2011 [2], the U.S. is the world's largest producer and accounted for approximately $15 \%$ of world production of cow's milk in 2011. Milk production is a $\$ 39.5$ billion/yr industry in the U.S., second only to beef among livestock and equal to corn [2]. Strategies to increase industry sustainability include building upon life cycle assessment (LCA) findings, developing a measuring and reporting framework, and awarding innovative excellence. These strategies have contributed to the U.S. dairy industry making great strides in some aspects of sustainability and efficiency (e.g., $41 \%$ smaller carbon footprint since 1944) and setting valuable goals in others (e.g., $25 \%$ greenhouse gas reduction by 2020 ; [3]). However, many producers have yet to formally address biodiversity, a critical ingredient to a healthy, functioning environment and overall sustainability [4]. Given that severe freshwater scarcity is a common phenomenon in many regions of the world, improving the governance of the world's limited annual freshwater supply is a major challenge, not only relevant to water users and managers but also to final consumers, businesses and policymakers in a more general sense (UNESCO, 2006). In industrialized countries, an average meat-eater consumes the equivalent of about $3600 \mathrm{~L}$ of water a day, which is 1.6 times more than the $2300 \mathrm{~L}$ used daily by people on vegetarian diets (assuming the vegetarians still consume dairy products [5]. Fresh water is a basic ingredient in the operations and supply chains of many companies. A company may face multiple risks related to failure in properly managing freshwater supplies: damage to its corporate image, the threat of increased regulatory control, financial risks caused by pollution, and inadequate freshwater availability for business operations [6]. The need for the food industry to take a responsible approach towards the sustainable use and conservation of fresh water is therefore vital. The 'water footprint' is an indicator of water use that looks at both direct and indirect water use by a consumer or producer [7]. The water footprint is a comprehensive indicator of freshwater resources appropriation, which goes beyond traditional restrictive measures of water withdrawal. Global consumption of livestock products is increasing steadily due to human population growth, poverty reduction and dietary changes raising the demand for already scarce freshwater and land resources.

Depletion of natural resources by humans, particularly for food production, is widely recognized as a significant threat to the sustainability of consumption [8]. Growing resource use intensities have led to groundwater depletion, soil loss, drying up of fresh water reserves and land degradation globally [8], [9]. Despite the mounting physical evidence of environmental degradation, the relation between consumption in specific regions and its impact on the environment in the production areas is usually not well recognized and quantified. Attempts to bridge this knowledge gap have motivated the development of various resource use indicators, such as the water and ecological footprints. The water footprint of a live animal consists of two components: the direct water footprint related to the drinking water and service water consumed and the indirect water footprint of the feed [7]. For beef cattle, the calculation of water footprint is most useful when an animal is considered at the end of its lifetime, because it is this total that will be allocated to the various resulting products (e.g., meat, leather). For dairy cattle, it is most straightforward to look at the water footprint of the animal per year, averaged over its lifetime, because one can easily relate this annual animal water footprint to its average annual milk production. Therefore, the water footprint of an animal can be expressed 
in terms of $\mathrm{m}^{3} / \mathrm{yr} / \mathrm{animal}$, or, when summed over the lifetime of the animal, in terms of $\mathrm{m}^{3} /$ animal. The water footprint of an animal can thus be expressed as sum of the water related to feed, drinking water and service water consumption. The feed water footprint generally dominates the other components by far. Service water refers to the water used for cleaning the area occupied by the animals, washing the animal and carrying out other services necessary to maintain the environment.

Milk production had a higher proportion of blue to green water footprint than meat production did. The contribution of blue water footprint to the total water footprint per tonne of milk produced ranged from $2 \%$ to $19 \%$ across all production systems. A grey footprint is present but represents only a very small proportion of the footprint per tonne of product. The grey footprint therefore is not carried forward in water footprint analysis of dairy products. The demand of water for milk production is mainly determined by the total numbers, feed conversion efficiency and diet composition of livestock. For cattle milk, studies reveal that the humid production system had the smallest water and land footprints per tonne. Furthermore, the study showed that the water footprint for milk from sheep and goats are much smaller than for cattle and camels. There is a pressing need for research focusing on advancing our understanding of the factors constraining the uptake of better feeding strategies and more investment in improved feed production. An understanding of the sustainability of the current milk production practices and implications of attempts to optimize interaction of the production parameters governing resource use efficiency in each country would enrich the capacity to develop the most resource efficient production practices.

\section{Methodology}

Here in this paper water intensity has been used as a measure of water footprint analysis. Water intensity is calculated for dairy industry in India. Primary survey has been done in Pondicherry Coop. Milk Supply Society (Established in 1971) in India. Secondary data has been used in order to analyse the virtual water footprint in dairy industry in India [10].

\section{DISCUSSION AND RESULTS}

Primary survey has been conducted in Pondicherry Coop. Milk Supply Society. (Established in 1971).Daily production of milk is 1.2 lakh L/ day. Ground water is used for production. Water consumption of indigenous as well as crossbred cows and that in the factory are taken into account in order to estimate the virtual water content in the dairy industry.

The functional relationship between water productivity in milk production, and cattle inputs and outputs can be expressed as:

$$
\sigma_{\text {dairy, } j}=Q_{M P} / \Delta_{\text {water }}
$$

where $Q_{M P}$ is the average daily milk yield of a livestock over the entire life cycle.

$$
\Delta_{\text {water }}=\omega_{d f} / Q_{d f}+\omega g f / Q_{d f}+\Delta_{d r i n k}
$$

where $Q d f, Q g f$ : average weights of dry and green fodder $(\mathrm{kg} /$ day $), \omega_{d f}, \omega_{g f}$ : water used for dry and green fodder( $\mathrm{L} / \mathrm{kg} /$ day $)$

Data on average feed and fodder fed to livestock, water used by dairy cows and average daily milk yield per cow is taken from Singh and Kumar (2004) (see Table I to Table III).

TABLE I: AVERAGE FEED AND FODDER FED TO LIVESTOCK

\begin{tabular}{|l|l|l|}
\hline $\begin{array}{l}\text { Fed to livestock } \\
\text { (kg/day) }\end{array}$ & INDIGENOUS COW & CROSSBRED COW \\
\hline GREEN FODDER & 12.92 & 14.41 \\
\hline DRY FODDER & 5.07 & 4.33 \\
\hline
\end{tabular}

Source: Singh and Kumar (2004).

TABLE II: WATER CONSUMED BY DAIRY COWS

\begin{tabular}{|l|l|l|}
\hline Fed to livestock & INDIGENOUS COW & CROSSBRED COW \\
\hline GREEN FODDER & 40 (lts/kg/day) & $100(\mathrm{lts} / \mathrm{kg} / \mathrm{day})$ \\
\hline DRY FODDER & 4280 (lts/kg/day) & $4590(\mathrm{lts} / \mathrm{kg} /$ day $)$ \\
\hline $\begin{array}{l}\text { DRINKING } \\
\text { WATER }\end{array}$ & $52.6($ lts/day) & $60.2(\mathrm{lts} /$ day $)$ \\
\hline
\end{tabular}

Source: Singh and Kumar (2004).

TABLE III: AVERAGE DAILY MILK YIELD PER COW

\begin{tabular}{|c|c|}
\hline INDIGENOUS COW & 2.98 (lts/day) \\
\hline CROSSSBRED COW & 4.46 (lts/day) \\
\hline
\end{tabular}

Source: Singh and Kumar (2004).

\begin{tabular}{|c|c|c|}
\hline \multicolumn{3}{|c|}{ STAGES } \\
\hline $\begin{array}{l}\text { Stages of dairy } \\
\text { industry }\end{array}$ & $\begin{array}{l}\text { Milk: Water } \\
\text { ratio }\end{array}$ & $\begin{array}{l}\text { water consumed } \\
\text { (L/day) }\end{array}$ \\
\hline BLUST COOLER & $5: 1$ & 24000 \\
\hline HEATING & $1: 2$ & 240000 \\
\hline CHILLING & $1: 3$ & 360000 \\
\hline
\end{tabular}

TABLE IV: MILK WATER RATIO AND WATER CONSUMED IN DIFFERENT

Source: Singh and Kumar (2004).

The water intensity for indigenous and crossbred cow is calculated putting values in equation 1) and equation 2) from the above data.

\section{A. Virtual Water}

\section{1) Indigenous cow}

Total water consumed by individual indigenous cow is calculated as:

$$
\Delta_{\text {water }}=899 \mathrm{~L} / \text { day }
$$

Total water productivity is given by:

$$
\sigma_{\text {dairy }, j}=0.0033
$$

Thus water intensity $=1 / \sigma=303.03$

\section{2) Crossbred cow}

Total water consumed by individual cross bred cow is calculated as:

$$
\Delta_{\text {water }}=1127.19 \text { L./day }
$$

Water productivity is calculated as: 


$$
\sigma_{\text {dairy, } j}=0.0039
$$

Thus water intensity $=1 / \sigma=256.41$

\section{B. Scenario in the Dairy Factory}

According to the primary survey data the factory produces 1.2 lakh litres of milk per day. Water is used in specific ratios in the different stages of the milk manufacturing process. We represent the relevant data in Table IV.

Thus total water consumed $(T W C)$ per day is:

$$
T W C=624000 \text { L/day }
$$

Thus, water productivity $=0.192$

We get water intensity as inverse of water productivity. Thus water intensity is 5.2.

Now, to get total water intensity we deal with indigenous and crossbred cows as two different cases:-

\section{Case 1: Milk from indigenous cow used in the factory}

Total water intensity in this case is taken as a sum of results which have been calculated previously. It is equal to 308.2.

\section{Case 2: Milk from crossbred cow used in the factory}

Here, total water intensity is 261.61 .

Water intensity is more since the daily milk yield per crossbred cow is almost double than that of the indigenous cows.

\section{CONCLUSION}

Understanding the water footprint (WF) of a nation is highly relevant for developing well-informed national policy. Conventional national water use accounts are restricted to statistics on water withdrawals within their own .National WF accounts extend these statistics by including data on rainwater use and volumes of water use for waste assimilation and by adding data on water use in other countries for producing imported products, as well as data on water use within the country for making export products .The WF is a measure of humans' appropriation of freshwater resources and has three components: blue, green, and gray. Quantifying and mapping national WFs has been an evolving field of study since the introduction of the WF concept in the beginning of this century.

With increasing water scarcity, there is a growing interest in improving goods water productivity. WF benchmarks as developed in this study can be used to provide an incentive for respective industries to reduce the WF of their products towards reasonable levels and thus use water more efficiently. The main challenge ahead is to develop tools that enable the management of pressure indicators with the complexity of water, providing relevant information in real time and directing the corporate strategy towards a more sustainable business.

Indian industrial water footprint lags far behind in sustainable use of water. Initiatives both by the government and individuals have to be taken to decrease the WF in industries in India.

\section{ACKNOWLEDGEMENT}

Thanks are due to Pondicherry Coop. Milk Supply Society for providing valuable data. The authors are grateful to the host institute, Madras School of Economics.

\section{REFERENCE}

[1] A. Y. Hoekstra and A. K. Chapagain, Globalization of Water: Sharing the Planet's Freshwater Resources, UK: Blackwell Publishing, Oxford, 2008, ch. 1-2.

[2] United States Department of Agriculture, Economic Research Service (USDA-ERS). U.S. dairy situation at a glance. [Online]. Available: http://www.ers.usda.gov/dataproducts/dairy-data.aspx

[3] J. L. Capper, R. A. Cady, and D. E. Bauman. (March 2009). The environmental impact of dairy production: 1944 compared with 2007. J. Anim. Sci. [Online]. pp. 2160-2163. Avaliable:www.agron.iastate.edu/Courses/agron515/Cap peretal.pdf

[4] K. Millar, P. H. West, and B. Nerlich, Ethical Futures: Bioscience and Food Horizons, Nottingham, United Kingdom:Eursafe, 2009, ch. 2-4.

[5] P. W. Gerbens-Leenes, M. M. Mekonnen, and A.Y. Hoekstra, "The water footprint of poultry, pork and beef: A comparative study in different countries and production systems," pp. 26-31, 2013.

[6] D. A. Rondinelli and M. A. Berry, "Environmental citizenship in multinational corporations: social responsibility and sustainable development," European Management Journal, vol. 18, no. 1, pp. 70-84, 2000.

[7] A. Y. Hoekstra, Virtual Water Trade: Proceedings of the International Expert Meeting on Virtual Water Trade, Delft, the Netherlands, 2003.

[8] D. J. Campbell, D. P. Lusch, T. A. Smucker, and E. E. Wangui, "Multiple methods in the study of driving forces of land use and land cover change: A case study of SE Kajiado District, Kenya," Hum. Ecol., vol. 33, pp. 763-794, 2005.

[9] D. O. Oago and E. O. Odada, "Sediment impacts in Africa's transboundary lake/river basins: case study of the east African great lakes," Aquat. Ecosyst. Health, vol. 10, pp. 23-32, 2007.

[10] O. P. Singh and M. D.Kumar. (July 2004). Impact of dairy farming on agricultural water productivity and irrigation water user. [Online] Available: http://publications.iwmi.org/pdf/H042638.pdf

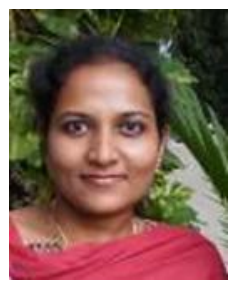

Zareena Begum Irfan was born in Pondicherry, India on March 27, 1981. Dr. Irfan did her entire schooling from St. Joseph of Cluny Convent, Pondicherry, India and later received her master's degree in integrated science program from the Pondicherry Central University (2003) and $\mathrm{PhD}$ (2007) from the Indian Institute of Technology Roorkee, India. Dr. Irfan's major field of interest is towards water consumption,

conservation and purification demand supply pattern analysis especially for developing countries. One major interest factor of her research work is the interdisciplinary perspective of the environmental resource and economics.

She is currently serving as an associate professor of environmenta economics at the Madras School of Economics, Chennai, Tamil Nadu, India. She has been involved in research related to water pollution, urban hydrology, arsenic-related environment-health-development nexus, environmental valuation, and ecotourism. She has been a faculty member at the Madras School of Economics since 2007. She is the author or co-author of more than thirty international journal publications and conference proceeding papers.

Dr. Irfan has also contributed many research works in the form of chapters of edited books. The latest contributions of the Dr. Irfan deal with the conservation of biodiversity and resource conservation. Dr. Irfan holds the key positions of being member in most of the editorial boards of research journals of Taylor \& Francis group and Springer group.

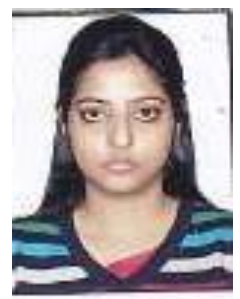

Mohana Mondal was born in Burdwan district, West Bengal on June 23, 1992. She holds a B.Sc. degree in economics from Calcutta University, Kolkata, India (2013) and a M.Sc degree in economics from Madras School of Economics, Chennai, India (2015).

She is currently a research associate at Madras School of economics, Centre of Excellence in Environmental Economics. Miss Mondal is a gold medal holder in her master's degree for topping the environmental economics course, batch 2013-2015 in her institution. 